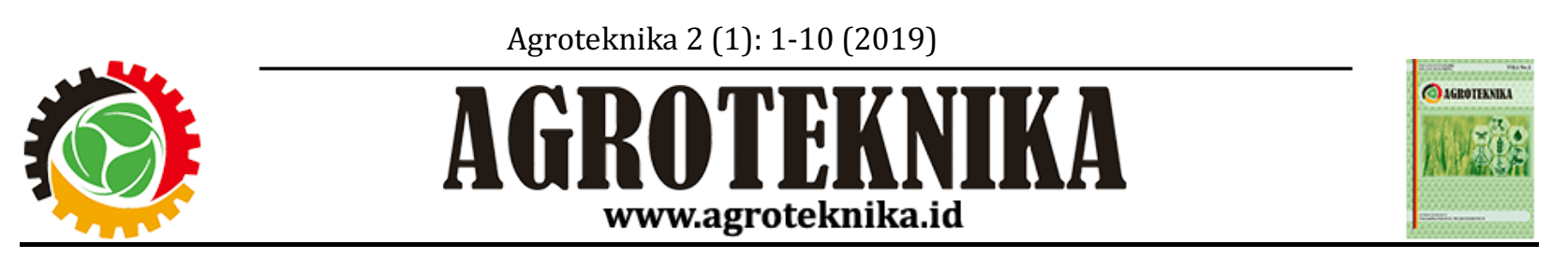

\title{
Pengaruh Perbandingan Serbuk Santan dan Gula dalam Pembuatan Manisan Instan Beras Rendang terhadap Penerimaan Konsumen dengan Analisis Sensori Uji Pembeda
}

\section{The Effect of Ratio of Coconut Milk Powder and Sugar in Making Instant Manisan Beras Rendang to Consument Accepted with a the Sensory Differential Test Analysis}

\author{
Risa Meutia Fiana ${ }^{*}, 1$, Wenny Surya Murtius ${ }^{1}$, Aurian Ming ${ }^{2}$ \\ ${ }^{1}$ Lecture of Agricultural Product Technology, ${ }^{2}$ Student of Agricultural Product Technology \\ Faculty Of Agricultural Technology, Andalas University 25163 \\ *Penulis Korespondensi \\ Email: risameutia@ymail.com
}

\begin{abstract}
Abstrak. Penelitian ini telah dilaksanakan di Laboratorium Kimia, Biokimia Hasil Pertanian dan Gizi Pangan, Laboratorium Teknologi dan Rekayasa Proses Hasil Pertanian Fakultas Teknologi Pertanian, Laboratorium Bioteknologi Ternak Fakultas Peternakan dan laboratorium Tablet Fakultas Farmasi pada bulan Juli sampai Agustus 2018. Tujuan penelitian ini adalah mengetahui perbandingan terbaik secara organoleptik produk beras rendang instan dengan uji pembeda. Metode penelitian yang digunakan adalah Rancangan Acak Lengkap dengan 5 perlakuan dan 3 ulangan, yang mana perlakuan A (35\% serbuk santan : 15\% gula), B (30\% serbuk santan : 20\% gula), C (25\% serbuk santan : 25\% gula), D (20\% serbuk santan : $30 \%$ gula), E (15\% serbuk santan : $15 \%$ gula). Berdasarkan uji pembeda terhadap produk beras redang instan, didapatkan hasil terbaik yaitu pada perlakuan D dengan perbandingan serbuk santan dan gula 20\%:30\% yang memiliki warna, aroma, rasa dan tekstur yang mirip dengan beras rendang tradisional..
\end{abstract}

Kata kunci: beras rendang, gula, serbuk santan

Abstract. This research has been carried out in the Laboratory of Chemistry, Agricultural Biochemistry and Food Nutrition, Laboratory of Technology and Agricultural Process Engineering Faculty of Agricultural Technology Laboratory of Animal Husbandry Biotechnology Faculty of Animal Husbandry, and Laboratory of Tablet Faculty of Pharmacy in July to August 2018. The aims of find out the best ratio in organoleptic instant beras rendang product with a differentiation test. This research method used a completely randomized design with 5 treatments and 3 replications, which treatments A (35\% coconut milk powder : 15\% sugar), B (30\% coconut milk Powder : 20\% Sugar), C (25\% coconut milk Powder : 25\% Sugar), D (20\% Coconut Milk Powder : 30\% Sugar), E (15\% Coconut Milk Powder : 15\% Sugar). Tests carried out included sensory analysis by differentiating test. Based on the and differentiation test for instant beras rendang products, the best product is instant beras rendang with $D$ treatment that is ratio of coconut milk powder and sugar is 20\%:30\% has a color, flavour, taste and texture simillar to tradisional beras rendang.

Keywords: beras rendang, cuconut milk powder, sugar

\section{Pendahuluan}

Beras rendang merupakan makanan tradisional Sumatera Barat yang berasal dari Kota Payakumbuh yangdijadikan sebagai buah tangan. Beras rendang terdiri dari dua bahan utama yaitu 
beras ketan yang direndang kemudian dijadikan tepung dan manisan yang terdiri dari larutan santan dan gula. Bahan tersebut kemudian diaduk rata dan dicetak (Erina, wawancara 3 Maret 2018). Produsen pembuatan Beras Rendang Erina Payakumbuh menyebutkan bahwa beras rendang yang diproduksi di Payakumbuh memiliki umur simpan lebih kurang satu minggu, hal ini disebabkan karena kandungan minyak yang tinggi.Produk dengan kandungan minyak yang tinggi mudah mengalami kerusakan akibat oksidasi dan hidrolisis yang menimbulkan ketengikan pada produk (Angelia, 2016). Kandungan minyak yang tinggi pada manisan beras rendang berasal dari santan. Menurut Winarno (2014) santan memiliki nutrisi yang lengkap dan mudah mengalami kerusakan selama penyimpanan sehingga dapat menjadi media tumbuh bagi mikroorganisme pembusuk.

Sibuknya kegiatan manusia pada era modern menuntut manusia untuk memenuhi kebutuhannya secara instan dan cepat. Tidak ada pengembangan terhadap produk beras rendang dapat menyebabkan makanan ini akan hilang karena tidak terwariskan. Teknologi pengolahan yang dapat diterapkan untuk memudahkan konsumen dalam menikmati makanan tradisional beras rendang adalah dengan cara mengeringkan larutan manisan beras rendang ke bentuk serbuk, sehingga dihasilkan produk berbentuk instan. Pangan instan merupakan bahan makanan yang mengalami proses pengeringan air, sehingga mudah larut dan mudah disajikan hanya dengan menambahkan air panas atau air dingin(Futriani, 2017).

Pengeringan Makanan dapat dilakukan dengan menggunakan alat spray dryer.Keuntungan pengeringan menggunakan alat spray dryer adalah pengeringan yang cepat, retensi produk dalam ruang pengering singkat dan produk akhir yang dihasilkan siap dikemas ketika proses pengeringan selesai. Pembuatan manisan instan menggunakan spray dryer membutuhkan bahan pengisi yang berfungsi untuk melindungi komponen bahan pangan yang sensitif, mengurangi kehilangan nutrisi, mengubah komponen bahan pangan bentuk cair ke bentuk padat yang lebih mudah ditangani. Penggunaan maltodekstrin sebagai pengisi menyebabkan ukuran partikel serbuk yang dihasilkan halus dibandingkan dengan bahan pengisi lainnya seperti gum arab atau pati berlemak yang menyebabkan serbuk berukuran lebih besar (Yousefi, 2011). Hayati, Dewi, dan Nugrahani, (2015)melakukan penelitian tentang pengaruh konsentrasi maltodekstrin terhadap rendemen pada pembuatan santan kelapa bubuk (coconut milk powder) dengan perlakuan variasi penambahan maltodekstrin yaitu dengan konsentrasi $2 \%, 4 \%, 6 \%, 8 \%$, dan $10 \%$, didapatkan pada variasi konsentrasi maltodekstrin dengan kadar 2\% diperoleh rendemen santan kelapa bubuk terendah yaitu 4,0038\% sedangkan rendemen terbesar diperoleh pada konsentrasi maltodekstrin dengan kadar 10\% yang memiliki rendemen santan kelapa bubuk yaitu 6,2071\%.

Penelitian pendahuluan telah dilakukan terhadap pengeringan santan dengan konsentrasi maltodekstrin $12 \%$ dan didapatkan hasil serbuk santan yang halus, warna putih dan memiliki 
aroma santan yang kuat. Metode yang dapat digunakan untuk membuat tepung beras rendang instan adalah dengan mengeringkan santan ke bentuk bubuk dan dilakukan pencampuran terhadap komposisi lainnya dengan formulasi yang berbeda sehingga didapatkan formulasi tepung instan beras rendang yang memiliki karakteritik sama dengan beras rendang tradisional. Dari latar belakang diatas maka penulis melakukan penelitian terhadap perbedaan jumlah penambahan serbuk santan dan gula terhadap tepung beras rendang instan dengan perlakuan penambahan serbuk santan dan gula yaitu 35\%: $15 \%, 30 \%: 20 \%, 25 \%: 25 \%, 20 \%: 30 \%, 15 \%: 35 \%$..

Tujuan dari penelitian ini adalah untuk mendapatkan formulasi beras rending instan yang memiliki warna, aroma, rasa dan tekstur yang sama dengan beras rending yang sudah ada di pasaran sekarang. Analisis yang tepat digunakan untuk mencapai tujuan penelitian ini yaitu analisis sensoris uji pembeda.

\section{Bahan dan Metode}

\section{Tempat dan Waktu}

Penelitian ini telah dilaksanakan di Laboratorium Kimia Biokimia Hasil Pertanian dan Gizi Pangan, Laboratorium Teknologi Rekaya dan Proses Hasil Pertanian Fakultas Teknologi Pertanian, Laboratorium Bioteknologi Ternak Fakultas Peternakan, dan Laboratorium Tablet Fakultas Farmasi Universitas Andalas dari bulan JunisampaiAgustus 2018.

\section{Bahan dan Alat}

Bahan baku yang digunakan pada penelitian ini adalah gula pasir putih merk Gulaku, kelapa masak (ditandai dengan warna kulit kelapa kuning ke coklatan), garam, vanili, air, tepung beras rendang, dan bahan pengisi maltodekstrin RTU (Ready to Use).

Alat yang digunakan untuk pembuatan tepungberas rendang instanadalah wadah plastik, baskom, sendok pengaduk, gelas ukur, saringan santan,spray dryer. Alat untuk analisa produk adalah pipet, cawan aluminium, cawan porselen, gegep,tanur, oven, desikator, tabung reaksi, erlenmeyer, gelas piala, tungku pemijaran, stopwatch, refraktometer.

\section{Pelaksanaan Penelitian}

\section{Persiapan Bahan Baku}

Santan

Kelapatua (yang ditandai dengan warna kuning kecoklatan) diparut kemudian santan kelapa diperas menggunakan air hangat suhu 60oC. Perbandingan penambahan air dan kelapa parut yaitu 2:1. Santan yang diperoleh kemudian dilakukan pemisahan krim dan skim santan. Santan didiamkan selama 30 menit, kemudian diambil bagian skim santan.

Gula Halus 
Gula yang digunakan adalah gula pasir putih kemudian dihaluskan dengan menggunakan blender merek Philips Cucina dengan kecepatan no 3. Partikel gula halus yang sudah diblender selama satu menit dengan kecepatan no 3 memiliki ukuran partikel yang sama dengan gula halus hasil mesin grinder olahan pabrik yaitu sekitar $0,15 \mathrm{~mm}$.

Beras Ketan

Beras ketan yang telah direndang dan dijadikan tepung diperoleh dari penjual oleh-oleh beras rendang "Erina" kota Payakumbuh.

Pembuatan Serbuk Santan (Mujumdar \& Arun, 2006)

Diukur berat santan $1000 \mathrm{~g}$ kemudian tambahkan garam,kemudian maltodekstrin sebanyak Tahap pengeringan menggunakan alat pengering spray dryer,

\section{Formulasi Tepung Beras Rendang Instan}

Serbuk santan yang telah diperoleh dicampurkan kedalam formulasi bahan beras rendang dengan konsentrasi yang berbeda beda. Formulasi penambahan serbuk santan dan gula dapat dilihat pada Tabel 1.

Tabel 1. Formulasi Tepung Beras Rendang Instan.

\begin{tabular}{llllll}
\hline Komposisi & \multicolumn{5}{c}{ Perlakuan } \\
\cline { 2 - 6 } & $\mathrm{A}$ & $\mathrm{B}$ & $\mathrm{C}$ & $\mathrm{D}$ & $\mathrm{E}$ \\
\hline Serbuk (\%) & 35 & 30 & 25 & 20 & 15 \\
Santan (\%) & & & & & \\
Gula (\%) & 15 & 20 & 25 & 30 & 35 \\
Tepung beras & 50 & 50 & 50 & 50 & 50 \\
Ketan (\%) & & & & & \\
\hline
\end{tabular}

\section{Proses Penyajian Tepung Instan Beras Rendang}

Tepung instan beras rendang terdiri dari dua jenis yaitu serbuk manisan dan tepung beras ketan (TBK). Serbuk manisan terdiri dari campuran serbuk santan, gula halus, garam, dan vanili yang telah dicampur sesuai formulasi. TBK disediakan secara terpisah dari serbuk manisan. Berikut adalah tahap penyajian tepung instan beras rendang.

1. Serbuk manisan diseduh dengan air sebanyak $200 \mathrm{~g}$ kemudian dipanaskan dengan suhu $\pm 70 \mathrm{oC}$ selama 30 menit atau sampai manisan kental (larutan tidak putus saat diangkat)

2. Campurkan manisan dengan TBK sebanyak 50 g kemudian diaduk sampai rata dan adonan dapat di cetak.

3. Produk beras rendang yang baik ditandai dengan permukaan yang licin, dan tidak retak.

\section{Pengamatan}

Pengamatan yang dilakukan pada penelitian ini yaitu pengamatan terhadap serbuk santan dan pengamatan terhadap produk beras rendang instan. Dilakukan pengujiananalisa sensori uji embeda 


\section{Hasil dan Pembahasan}

\section{Analisis Serbuk Santan}

Analisa yang dilakukan yaitu uji kadar air, kadar abu, kadar lemak dan rendemen. Hasil analisa bahan baku dapat dilihat pada Tabel 2 .

Tabel 2. Nilai analisa bahan baku

\begin{tabular}{ll}
\hline Parameter & Rata-rata $(\%) \pm \mathrm{SD}$ \\
\hline Rendemen & $4,94 \pm 0,259$ \\
Kadar air & $5,60 \pm 0,283$ \\
kadar abu & $0,60 \pm 0,283$ \\
kadar lemak & $16,61 \pm 0,799$ \\
\hline
\end{tabular}

Rendemen serbuk santan yang diperoleh adalah 4,94\%. Maltodekstrin yang ditambahkan akan mempengaruhi rendemen serbuk santan yang dihasilkan. Fungsi dari maltodekstrin adalah sebagai bahan pengisi yang meningkatkan total padatan dalam bahan sehingga meningkatkan rendemen yang dihasilkan (Hayati et al, 2015). Jumlah maltodekstrin yang ditambahkan pada pembuatan serbuk santan adalah 12\%, hal ini sesuai dengan yang dilakukan oleh Srihari (2010) yang melakukan penelitian terhadap penambahan maltodekstrin pada pembuatan santan kelapa bubuk dimana pada penambahan maltodekstrin $12 \%$ diperoleh serbuk santan yang memiliki rendemen tertinggi, kadar air terendah dan menghasilkan serbuk santan yang halus, warna putih dan memiliki aroma santan yang kuat.

Serbuk santan yang dihasilkan menunjukkan nilai kadar air yang baik yaitu 5,60\%. Menurut Fuadah (2014) bahan yang memiliki kadar air kurang dari 6\% dapat disimpan dalam waktu yang lama. Kadar air pada serbuk santan dipengaruhi oleh konsentrasi maltodekstrin yang ditambahkan dan suhu pengeringan yang digunakan. Kadar air pada serbuk santan berpengaruh terhadap umur simpan, penampakan dan kecepatan larut serbuk santan (Srihari, 2010). Semakin tinggi kadar air serbuk santan maka umur simpan produk singkat karena serbuk santan memiliki kandungan lemak yang tinggi sehingga apabila bereaksi dengan air maka akan menyebabkan ketengikan. Semakin tinggi kadar air serbuk santan maka waktu melarutnya akan lama, hal ini disebabkan tingginya kandungan air dapat menurunkan sifat higroskopis (menyerap air) pada bahan.

Kadar abu merupakan residu anorganik dari proses pembakaran atau oksidasi komponen organik bahan pangan. Kadar abu dari serbuk santan yang didapatkan yaitu 0,60\%. Kadar abu menunjukkan total mineral yang terdapat dalam bahan pangan. Kandungan mineral pada serbuk santan berasal dari santan yang digunakan. Mineral yang terdapat pada santan yaitu kalsium, fosfor, dan kalium (Winarno, 2014). 
Kadar lemak serbuk santan yang dihasilkan memiliki yaitu 16,61\%. Santan murni memiliki Kandungan lemak 34,3\% (Sutanto dan Soegiarto, 2013). Tinggi rendahnya lemak pada bahan pangan akan berpengaruh terhadap umur simpan dan karakteristik produk. Pada pembuatan beras rendang instan, santan yang digunakan sudah dalam bentuk serbuk, dimana pada saat pembuatan serbuk santan krim dan skim dari santan dipisahkan dan yang digunakan adalah skim santan. Skim dari santan merupakan bagian yang miskin minyak dan krim dari santan merupakan bagian yang kaya akan minyak (Tarwiyah, 2001). Pemisahan skim dan krim pada santan bertujuan untuk menghindari kerusakan pada serbuk santan, karena kandungan lemak yang tinggi akan mengakibatkan ketengikan pada produk dan daya simpan dari produk singkat (Angelia, 2006). Lemak yang tinggi pada produk akan cepat mengalami ketengikan karena adanya reaksi oksidasi (Winarno, 2004).

\section{Analisis Sensori Uji Pembeda}

\section{Warna}

Berdasarkan data yang diperoleh dari 25 orang panelis didapatkan bahwa produk A dan B memiliki warna yang sama dengan beras rendang tradisional. Berdasarkan jumlah panelis terkecil untuk menyatakan benda nyata tingkat kesalahan 5\%, 1\% dan 0,1\% masing masing adalah 18,20 , 21 panelis. Atribut warna produk dengan perlakuan A dan B tidak berbeda nyata karena jumlah panelis yang menjawab berbeda belum memenuhi jumlah yang ditetapkan. Warna dari perlakuan C, D, dan E berbeda nyata pada tingkat 5\% karena jumlah panelis yang menilai berbeda telah memenuhi jumlah yang ditetapkan. Warna yang dihasilkan dari beras rendang instan adalah putih kekuningan sampai putih kecoklatan. Warna yang dihasilkan oleh produk dipengaruhi oleh jumlah gula yang ditambahkan.

Perbedaan warna beras rendang instan pada setiap perlakuan dapat dilihat pada Tabel 9.

Tabel 3. Penilaian Panelis terhadap Perbedaan Warna Beras Rendang Instan dengan Beras Rendang Tradisional.

\begin{tabular}{lcc}
\hline Perlakuan & $\begin{array}{c}\text { Jumlah } \\
\text { Nilai }\end{array}$ & $\begin{array}{c}\text { Tingkat Beda } \\
\text { Nyata }\end{array}$ \\
\hline $\begin{array}{l}\text { A (Serbuk santan 35\%: } \\
\text { Gula 15\%) }\end{array}$ & 16 & - \\
B (Serbuk Santan 30\%: & 16 & - \\
Gula 20\%) & & \\
C (Serbuk Santan 25\%: \\
$\begin{array}{l}\text { Gula 25\%) } \\
\text { D (Serbuk Santan 20\%: } \\
\text { Gula 30\%) }\end{array}$ & 18 & $5 \%$ \\
\hline
\end{tabular}


E (Serbuk Santan 15\%: $\quad 19 \quad 5 \%$

Gula $35 \%$ )

Reaksi karamelisasi pada gula yang menyebabkan warna kecoklatan pada produk. Bila suatu larutan sukrosa diuapkan maka konsentrasinya akan meningkat, dan bila gula yang telah cair tersebut dipanaskan terus hingga suhunya melampaui titik leburnya, maka mulailah terjadi karamelisasi sukrosa dengan penambahan cita rasa (Gaffar, 2017). Semakin tinggi penambahan gula maka warna beras rendang instan yang dihasilkan akan semakin coklat sebaliknya semakin sedikit penambahan gula maka warna beras rendang putih kekuningan.

\section{Aroma}

Perbedaan aroma beras rendang instan dengan beras rendang tradisional dapat dilihat pada Tabel 4.

Tabel 4. Penilaian Panelis terhadap Perbedaan Aroma Beras Rendang Instan dengan Beras Rendang Tradisional

\begin{tabular}{lcc}
\hline Perlakuan & $\begin{array}{c}\text { Jumlah } \\
\text { Nilai }\end{array}$ & $\begin{array}{c}\text { Tingkat Beda } \\
\text { Nyata }\end{array}$ \\
& & $5 \%$ \\
\hline A (Serbuk santan & 18 & \\
$35 \%$ : Gula 15\%) & & \\
B (Serbuk Santan 30\%: & 19 & $5 \%$ \\
Gula 20\%) & \\
C (Serbuk Santan 25\%: & 15 & - \\
Gula 25\%) & \\
$\begin{array}{l}\text { D (Serbuk Santan 20\%: } \\
\text { Gula 30\%) }\end{array}$ & 10 & - \\
E (Serbuk Santan 15\%: & 19 & $5 \%$ \\
Gula 35 \%) & \\
\hline
\end{tabular}

Berdasarkan Tabel 4. dapat dilihat bahwa pada atribut aroma perlakuan A, B dan E dinyatakan berbeda pada tingkat $5 \%$. Perlakuan $\mathrm{C}$ dan $\mathrm{D}$ tidak dapat menyatakan adanya perbedaan karena jumlah panelis terkecil untuk menyatakan benda nyata tingkat kesalahan 5\%, $1 \%$ dan $0,1 \%$ masing-masing adalah $18,20,21$ panelis. Beras rendang memiliki aroma yang khas yaitu aroma beras ketan yang berasal dari penyangraian beras ketan. Salah satu tujuan dari penyangraian adalah untuk meningkatkan cita rasa dan flavour makanan, mengurangi zat toksik dan upaya pengawetan makanan (Arinola, 2014). Aroma pada beras rendang juga memiliki aroma yang wangi dari pemasakan manisan. Aroma dari manisan berasal dari pemasakan gula dan santan. Bila suatu larutan sukrosa diuapkan maka konsentrasinya akan meningkat, dan bila gula yang telah cair tersebut dipanaskan terus hingga suhunya melampaui titik leburnya, maka mulailah terjadi 
karamelisasi sukrosa (winarno, 2004). Terjadinya reaksi karamelisasi merupakan penyebab utama dalam pembentukan bau rasa pada suatu bahan (deMan, 1997).

Penambahan vanili dilakukan pada saat pembuatan serbuk santan sehingga serbuk santan yang dihasilkan memiliki aroma vanili. Semakin banyak penambahan gula maka aroma yang dihasilkan lebih cendrung memiliki aroma gula, sebaliknya semakin sedikit penambahan gula maka aroma yang dihasilkan lebih dominan aroma santan dan vanili. Perlakuan A dan B jumlah gula yg ditambahkan lebih sedikit dari serbuk santan yang ditambahkan sehingga menyebabkan aroma dari beras rendang lebih dominan aroma santan dan vanili. Perlakuan $\mathrm{C}$ dan $\mathrm{D}$ memiliki aroma yang sama dengan beras rendang tradisional karena jumlah penelis tidak dapat menyatakan adanya perbedaan. Perlakuan D terdapat perbedaan aroma disebabkan oleh jumlah gula yang ditambahkan lebih banyak sehingga aroma yang dihasilkan lebih dominan aroma gula.

\section{Rasa}

Perbedaan rasa beras rendang instan dengan beras rendang tradisional dapat dilihat pada Tabel 5.

Tabel 5. Penilaian Panelis Terhadap Perbedaan Rasa Beras Rendang Instan dengan Beras Rendang Tradisional.

\begin{tabular}{lcc}
\hline Perlakuan & $\begin{array}{c}\text { Jumlah } \\
\text { Nilai }\end{array}$ & $\begin{array}{c}\text { Tingkat } \\
\text { Beda }\end{array}$ \\
& Nyata \\
\hline $\begin{array}{l}\text { A (Serbuk santan 35\%: } \\
\text { Gula 15\%) }\end{array}$ & 25 & $0,1 \%$ \\
B (Serbuk Santan 30\%: & 23 & $0,1 \%$ \\
Gula 20\%) & \\
C (Serbuk Santan 25\%: & 19 & $5 \%$ \\
Gula 25\%) & & \\
D (Serbuk Santan 20\%: \\
Gula 30\%)
\end{tabular}

Berdasarkan hasil uji pembeda yang dilakukan antara beras rendang instan dengan beras rendang traditional perlakuan $\mathrm{A}, \mathrm{B}$ dan $\mathrm{C}$ dinyatakan berbeda dan perlakuan $\mathrm{D}$ dan $\mathrm{E}$ tidak dapat dinyatakan adanya perbedaan, karena jumlah panelis terkecil untuk menyatakan benda nyata tingkat kesalahan 5\%,1\% dan 0,1\% masing-masing adalah 18,20, 21 panelis, sehingga dapat dikatakan bahwa perlakuan D dan E memiliki rasa yang mirip dengan beras rendang tradisional. Beras rendang memiliki rasa yang manis. semakin sedikit penambahan serbuk santan dan semakin banyak penambahan gula, maka semakin manis rasa beras rendang. Tingkat kemanisan beras 
rendang dapat dilihat dari nilai total gula pada setiap perlakuan. Nilai total gula meningkat dari perlakuan A ke E, total gula tertinggi yaitu pada perlakuan E dengan nilai 27,13\%. Rasa pada beras rendang tidak saja berasal dari gula, namun juga dari komponen lain yang ditambahkan seperti garam, dan serbuk santan. Komponen rasa akan berinteraksi dengan komponen rasa primer, akibatnya menimbulkan peningkatan rasa atau penurunan intesitas rasa. Efek interaksi rasa berbeda beda pada tingkat konsetrasi yang berbeda.

\section{Tekstur}

Perbedaan Tekstur beras rendang instan dengan beras rendang tradisional dapat dilihat pada Tabel 14.

Tabel 6. Penilaian Panelis terhadap Perbedaan Tekstur Beras Rendang Instan dengan Beras Rendang Tradisional.

\begin{tabular}{lcc}
\hline Perlakuan & $\begin{array}{c}\text { Jumlah } \\
\text { Nilai }\end{array}$ & $\begin{array}{c}\text { Tingkat Beda } \\
\text { Nyata }\end{array}$ \\
\hline A (Serbuk santan & 19 & $5 \%$ \\
$35 \%$ : Gula 15\%) & & \\
B (Serbuk Santan & 21 & $0,1 \%$ \\
30\% : Gula 20\%) & & \\
C (Serbuk Santan & 18 & $5 \%$ \\
25\% : Gula 25\%) & & \\
D (Serbuk Santan & 17 & - \\
20\% : Gula 30\%) & & \\
E (Serbuk Santan & 17 & \\
15\% : Gula 35\%) & & \\
\hline
\end{tabular}

Berdasarkan Tabel 6. Dapat dilihat bahwa perlakuan A, B, dan C dinyatakan berbeda nyata secara berturut-turut yaitu 5\%,0,1\% dan 5\%. Perlakuan D dan E tidak dapat dinyatakan berbeda karena jumlah panelis terkecil untuk menyatakan benda nyata tingkat kesalahan 5\%, 1\% dan 0,1\% masing-masing adalah 18, 20, 21 panelis. Perlakuan D dan E memiliki tekstur yang mirip dengan beras rendang tradisional hal ini berkaitan dengan total gula dan lemak yang dikandung. Semakin tinggi total gula maka beras rendang yang dihasilkan akan lebih keras. Menurut (2017) gula mengalami karamelisasi dan bersifat osmosis (mengikat air) sehingga air pada bahan rendah dan menyebabkan beras rendang sedikit keras. Semakin tinggi kandungan lemak dari beras rendang maka tekstur dari beras rendang akan lunak dan mengkilap karena kandungan minyak yang terdapat pada serbuk santan. 


\section{Kesimpulan}

Berdasarkan penelitian yang telah dilakukan, maka dapat diambil beberapa kesimpulan sebagai berikut Produk terbaik berdasarkan analisa sensori uji pembeda antara produk beras rendang instan dan produk beras rendang tradisional yaitu pada perlakuan D dengan perbandingan serbuk santan dan gula 20\%:30\% yang memiliki warna, aroma, rasa dan tekstur yang mirip dengan beras rendang tradisional.

\section{Daftar Pustaka}

Angelia, I. O. (2016). Reduksi Tingkat Ketengikan Minyak Kelapa dengan Pemberian Antioksidan Ekstrak Daun Sirih (Piper betle Linn). Jtech. 4 (1) : 32-36.

Arinola, S. D. (2014). Effect of Thermal Processing on The Nutritional, Antinutritional, and Antioxidan Properties of Tetracarpidium conophorum (African Walnut). Journal of Food Processing. 14 (1): 4.

deMan, M. J. (1997). Kimia Makanan. Bandung : ITB.

Erina. (2018). " Proses Pembuatan Beras Rendang" [wawancara]. 3 Maret 2018.

Futriani, D. (2017). Pengaruh Tingkat Perbandingan Kaldu Kepala Ikan Tuna dan Sari Brokoli Terhadap Sifat Fisiko Kimia dan Organoleptik Kaldu Ikan dalam Bentuk Instan. [Skripsi]. Padang : Universitas Andalas.

Fuadah, A., Sumarlan, S.H., \& Hendrawan, Y. (2014). Kajian Pembuatan Bumbu Dari Bawang Putih (Allium sativum) dan Daun Jeruk Purut (Cytrus hystrix) Menggunakan Pengering Tipe Rak. Jurnal Keteknikan Pertanian Tropis dan Biosistem. 2 (2). : 156-166.

Gaffar, R., Lahming \& Rais, M. (2017). Pengaruh Konsentrasi Gula Terhadap Mutu Selai Kulit Jeruk Bali (Citrus maxima). Jurnal Pendidikan Teknologi Pertanian. 3 (1) : S117 - S125.

Hayati, H. R., Dewi, A. K., Nugtahani, R. A., dan Satibi, L. (2015). Pengaruh Konsentrasi Maltodekstrin Terhadap Kadar Air Dan Waktu Melarutnya Santan Kelapa Bubuk (Coconut Milk Powder) Dalam Air. Jurnal Teknologi. 7 (1), 55-60.

Mujumdar, \& Arun, S. (2006). Metode Pengeringan Menggunakan Metode Spray Dryer (Continuous Driying). Banyumas : Universitas Jendral Sudirman.

Srihari, E., F. S. Lingganingrum., R. Hervita., \& H. Wijaya. (2010). Pengaruh Penambahan Maltodekstrin, pada Pembuatan Santan Kelapa Bubuk. Seminar Rekayasa Kimia dan Proses ISSN :1411- 4216, A-18:2 - A-18:3.

Sutanto \& Soegiarto, S. (2013). Pengaruh Penambahan Gum Arab dan Sukrosa Ester Terhadap Kestabilan Santan Kelapa Selama Penyimpanan. [Thesis]. Semarang : UNIKA Soegijapranata.

Tarwiyah, K. (2001). Tepung Aren. Jurnal Pengolahan Pangan. 3 (2) : 22-23. Dewan Ilmu Pengetahuan.

Winarno, F. G. (2004). Kimia Pangan dan Gizi. Jakarta: PT Gramedia Pustaka Utama.

Winarno, F. G. (2014). Kelapa Pohon Kehidupan. Jakarta: Gramedia Pustaka Utama.

Yousefi, S., Djomeh, Z., \& Mousavi, M. S. (2011). Effect of Carrier Type and Spray Drying on The Physicochemical Properties of Powdered and Reconstituted Pomegranate Juice (Punica granatum L.). Journal of Food Science and Technology, 48 (6) : 677- 684. 